\title{
PENERAPAN PROTOKOL KESEHATAN COVID-19 MAHASISWA UNIVERSITAS PAHLAWAN TUANKU TAMBUSAI TAHUN 2020
}

\author{
Putri Eka Sudiarti ${ }^{1}$, Zurrahmi $\mathbf{Z R}^{2}$, Marini Ariesta ${ }^{3}$ \\ Prodi S1 Keperawatan Universitas Pahlawan Tuanku Tambusai ${ }^{13}$ \\ Prodi D4 Kebidanan Universitas Pahlawan Tuanku Tambusai ${ }^{2}$ \\ putriekasugiarti@gmail.com, zurrahmi10@gmail.com
}

\begin{abstract}
Corona Virus Disease-19 or COVID-19 has been declared a pandemic or global outbreak by the World Health Organization (WHO). One of the countries affected by the COVID-19 outbreak is Indonesia. The form of the Indonesian government's action against the Covid-19 case is by making a new regulation where every activity carried out by the community must prioritize the COVID-19 prevention health protocol. This study aims to determine the description of the implementation of the COVID-19 health protocol for students at the University of Pahlawan Tuanku Tambusai 2020. This type of research is a descriptive study, with a quantitative approach. The sampling technique used in this research was purposive sampling technique, namely as many as 83 respondents. Respondents in this study were students of the Nursing Study Program at Universitas Pahlawan Tuanku Tambusai. Data collection used observation checklist sheet and questionnaire. The results of the research will be processed to see the distribution of the distribution of the implementation of the Covi-19 health protocol by respondents. female students were 70 people (84.33\%). About 78 (93.97\%) Students took measures to measure their hands, 82 (98.79\%) Students took ethical cough actions well. All 83 (100\%) students used masks and about 80 (96.38\%) students did physical distancing. In total, students have implemented the Covid-19 health protocol in accordance with the New Normal provisions by the government. This can be based on the fact that students are health students.
\end{abstract}

Keywords $\quad$ : Covid-19, health protocol, New Normal, Students

\begin{abstract}
ABSTRAK
Corona Virus Disease-19 atau COVID-19 telah ditetapkan sebagai pandemik atau wabah global oleh World Health Organization (WHO). Salah satu negara yang terdampak wabah COVID-19 adalah Indonesia. Bentuk tindakan pemerintah Indonesia terhadap kasus Covid-19 yaitu dengan membuat sebuah peraturan New Normal dimana setiap kegiatan yang dilaksanakan oleh masyarakat harus mengutamakan protokol kesehatan pencegahan COVID-19. Penelitian ini bertujuan untuk mengetahui gambaran penerapan protokol kesehatan COVID-19 Mahasiswa Universitas Pahlawan Tuanku Tambusai Tahun 2020. Jenis penelitian ini adalah penelitian deskriptif, dengan pendekatan kuantitatif. Teknik pengambilan sampel pada penelitian menggunakana teknik purposive sampling yaitu sebanyak 83 responden. Responden pada penelitian ini adalah mahasiswa Prodi S1 Keperawatan Universitas Pahlawan Tuanku Tambusai. Pengumpulan data menggunakan lembar ceklist observasi dan angket. Hasil peneltian akan diolah untuk melihat persebaran distribusi pelaksanaan protokol kesehatan Covi-19 yang dilakukan oleh responden. mayoritas mahasiswa berjenis kelamin Perempuan yaitu sebanyak 70 orang (84,33\%). Sekitar 78 (93,97\%) Mahasiswa melakukan tindakan mencuci tangan, $82(98,79 \%)$ Mahasiswa melakukan tindakan etika batuk dengan baik. Seluruh mahasiswa 83 (100\%) melakukan menggunakan masker dan sekitar 80 (96,38\%) mahasiswa melakukan physical distancing. Secara keseluruhan mahasiswa telah menerapkan protokol kesehatan Covid-19 sesuai dengan yang ketentuan New Normal oleh pemerintah. Hal ini dapat didasari karena mahasiswa merupakan mahasiswa kesehatan.
\end{abstract}

Kata Kunci : Covid-19, Mahasiswa, New Normal, Protokol Kesehatan 


\section{PENDAHULUAN}

Corona Virus Disease-19 atau COVID-19 telah ditetapkan sebagai pandemik atau wabah global oleh World Health Organization (WHO). COVID19 merupakan suatu jenis virus baru yang mulai menyerang manusia. COVID-19 tidak melayang di udara tetapi menempel pada benda atau anggota tubuh. COVID-19 ditularkan melalui kelelawar dan ular ke manusia, sedangkan penularan dari manusia ke manusia melalui droplet atau partikel air liur ketika penderita bersin atau batuk (WHO, 2020).

Pada tahun 2020, 210 negara di dunia telah dinyatakan positif terdampak COVID-19 dengan total kasus lebih dari 3.000.000 juta orang. Walaupun terdapat beberapa orang sembuh, namun lebih dari 200.000 orang tersebut meninggal dunia akibat COVID-19. Amerika Serikat menjadi negara dengan jumlah kasus COVID-19 terbanyak yaitu lebih dari 500.000 juta orang. Wabah COVID19 ini terus mengalami peningkatan yang signifikan hingga saat ini, sehingga WHO masih menetapkan COVID-19 sebagai pandemik global (Worldometers, 2020).

Salah satu negara yang terdampak wabah COVID-19 adalah Indonesia. Pada tanggal 1 Maret 2020,terdapat dua orang korban yaitu ibu dan anak terdeteksi positif COVID-19 (Susilo et al, 2020). Setelah ditelusuri mereka memiliki kontak dengan salah satu warga negara asing asal Jepang. Pada tanggal 25 September 2020, jumlah kasus positif COVID-19 di Indonesia mencapai angka 262.000 kasus, dalam perawatan 60064 orang, sembuh 191.853 orang dan jumlah meninggal sebanyak 10.105 orang. Jumlah dari wabah ini terus mengalami peningkatan yang signifikan dan sudah menyebar hampir di seluruh Provinsi Indonesia (Kemenkes, 2020a).

Salah satu Provinsi di Indonesia yang terkena dampak dari wabah COVID-
19 adalah Provinsi Riau. Jumlah orang yang terkomfirmasi COVID-19 di Provinsi Riau selalu meningkat setiap harinya. Pada tanggal 25 September 2020, sejumlah 6120 orang di Provinsi Riau terkomfirmasi COVID-19. Sekitar 2361 orang isolasi mandiri, 862 orang dirawat di Rumah Sakit, 2771 orang sembuh dan 126 orang meninggal (Dinkes, Provinsi Riau, 2020).

Kabupaten Kampar merupakan kabupaten kedua yang memiliki jumlah angka terkomfirmasi COVID-19 tinggi di Provinsi Riau. Terhitung tanggal 25 September 2020 terdapat 707 orang terkomfirmasi COVID-19 dengan sebaran 14 orang positif, isolasi mandiri 156 orang, 67 orang dirawat di Rumah Sakit, 465 orang sembuh dan 19 orang meninggal dunia. Hal ini membuat Kabupaten Kampar masuk pada zona merah (Dinkes, Provinsi Riau, 2020).

Kondisi Kabupaten Kampar yang termasuk pada zona merah tak membuat beberapa kegiatan dimasyarakat lumpuh total. Hal tersebut juga diperkuat dengan adanya peraturan pemerintah mengenai kebijakan new normal yang membuat masyarakat mulai melakukan aktivitas mereka sehari-hari (Hermawan, 2020). Beberapa kegiatan tersebut diantaranya perkantoran, perdagangan proses pembelajaran dan lain sebagainya. Salah satu instansi yang mulai menjalankan kegiatan pada masa new normal ini adalah Univeristas Pahlawan Tuanku Tambusai Riau.

Kebijakan pemerintah mengenai new normal memiliki beberapa ketentuan, diantaranya setiap kegiatan yang dilaksanakan harus mengutamakan protokol kesehatan pencegahan COVID-19 serta membatasi membatasi sentuhan dengan individu yang lainnya (Griffith, 2020). Hal tersebut tertuang dalam Surat Edaran Menteri Kesehatan Nomor HK.02.01/MENKES/335/2020 tentang Protokol Pencegahan Penularan Corona Virus Disease (Covid-19). Protokol kesehatan Pencegahan COVID-19 terdiri dari 7 bagian dalam mencegah penyebaran 
COVID-19 diantaranya penggunaan masker, cuci tangan dengan sabun (KEMENKES, 2020a). Namun, jika terdapat pengabaian pada protokol kesehatan, maka akan berakibat bertambahnya jumlah kasus COVID-19 dan berpotensi munculnya gelombang kedua (Marpaung, 2020).

Namun berdasarkan hasil pengamatan peneliti pada beberapa tingkat dan bagian masyarakat, masih banyak masyarakat atau instansi-instansi yang belum menerapkan Protokol Kesehatan Pencegahan COVID-19 secara keseluruhan. Salah satunya di Institusi pendidikan, walaupun penempatan tempat duduk mahasiswa sudah diatur berdasarkan protokol kesehatan COVID19 namun saat mahasiswa masih berkuruman saat jam istirahat.

Dalam penelitian ini peneliti bertujuan mengetahui Gambaran Penerapan Protokol Kesehatan COVID-19 Terkait Mencuci Tangan Dengan Sabun, Etika Batuk, Penggunaan Masker, Dan Physical Distancing yang dilakukan oleh Mahasiswa Universitas Pahlawan Tuanku Tambusai Tahun 2020.

\section{METODE}

Jenis penelitian ini adalah penelitian deskriptif melalui pendekatan penelitian pendekatan kuantitatif untuk mengetahui bagaimana penerapan protokol kesehatan COVID-19 yang dilakukan oleh Mahasiswa Universitas Pahlawan Tuanku Tambusai Tahun 2020. Penelitian ini dilakukan pada bulan Desember tahun 2020 di lingkungan kampus Universitas Pahlawan Tuanku Tambusai.

Populasi dalam penelitian ini adalah seluruh mahasiswa Universitas Pahlawan Tuanku Tambusai yang melakukan perkuliahan saat pandemi Covid-19. Sedangkan untuk sampel dalam penelitian ini adalah mahasiswa Prodi S1 Keperawatan angkatan pertama Fakultas Ilmu Kesehatan Universitas Pahlawan Tuanku Tambusai yang melakukan perkuliahan saat pandemi Covid-19 sebanyak 83 Mahasiswa dengan teknik purposive samping. Penetuan sampel ini didasarkan karena saat dilakukan penelitian hanya mahasiswa tersebut yang melakukan perkuliahan tatap muka dalam perkuliahan praktikum di labor.

Alat pengumpulan data yang digunakan dalam penelitian ini adalah berupa lembar ceklist observasi dan angket. Data yang digunakan dalam penelitian ini adalah data primer, yaitu data yang diperoleh dari observasi dan pengisian angket. Pengambilan data observasi dilakukan dengan mengobservasi tindakan protokol kesehatan pencegahan Cocid-19. Untuk data angket disebarkan melalui google form. Analisa data penelitian menggunakan analisis statistik untuk melihat distribusi frekuensi masing-masing data penelitian.

\section{HASIL}

\section{Karakteristik Responden}

Tabel 1. Distribusi Karakteristik Mahasiswa Prodi S1 Keperawatan

\begin{tabular}{lcc}
\hline $\begin{array}{c}\text { Jenis } \\
\text { Kelamin }\end{array}$ & $\begin{array}{c}\text { Frekuensi } \\
(\mathbf{f})(\mathbf{n = 8 3})\end{array}$ & $\begin{array}{c}\text { Persentase } \\
(\mathbf{\%})\end{array}$ \\
\hline Laki-laki & 13 & 15,66 \\
Perempuan & 70 & 84,33 \\
\hline \multicolumn{1}{c}{ Usia } & & \\
\hline 18 Tahun & 33 & 39,75 \\
\hline 17 Tahun & 50 & 60,24 \\
\hline
\end{tabular}

Berdasarkan tabel 1 diketahui bahwa mayoritas mahasiswa berjenis kelamin Perempuan yaitu sebanyak 70 orang $(84,33 \%)$.

\section{Penerapan Protokol Covid-19}

Tabel 2. Distribusi Frekuensi Penerapan Protokol COVID-19 oleh Mahasiswa S1 Keperawatan

\begin{tabular}{ccc}
\hline $\begin{array}{c}\text { Mencuci } \\
\text { Tangan }\end{array}$ & $\begin{array}{c}\text { Frekuensi } \\
(\mathbf{f})\end{array}$ & $\begin{array}{c}\text { Persentase } \\
(\boldsymbol{\%})\end{array}$ \\
\hline Dilakukan & 78 & 93,97
\end{tabular}




\begin{tabular}{|c|c|c|}
\hline $\begin{array}{l}\text { Tidak } \\
\text { dilakukan }\end{array}$ & 5 & 06,02 \\
\hline \multicolumn{3}{|c|}{ Etika Batuk } \\
\hline Baik & 82 & 98,79 \\
\hline Kurang & 1 & 0,01 \\
\hline Baik & & \\
\hline \multicolumn{3}{|c|}{ Pemakaian Masker } \\
\hline $\mathrm{Ya}$ & 83 & 100 \\
\hline TIdak & - & - \\
\hline \multicolumn{3}{|c|}{ Physical Distancing } \\
\hline Dilakukan & 80 & 96,38 \\
\hline $\begin{array}{l}\text { Tidak } \\
\text { dilakukan }\end{array}$ & 3 & 03,61 \\
\hline
\end{tabular}

Berdasarkan tabel 2. diketahui bahwa sekitar $78 \quad(93,97 \%) \quad$ Mahasiswa melakukan tindakan mencuci tangan, 82 $(98,79 \%)$ Mahasiswa melakukan tindakan etika batuk dengan baik. Seluruh mahasiswa 83 (100\%) melakukan menggunakan masker dan sekitar 80 (96,38\%) mahasiswa melakukan physical distancing.

\section{PEMBAHASAN}

Jenis kelamin mahasiswa pada penelitian ini didapatkan bahwa mahasiswa perempuan lebih banyak yaitu 84, 33\% dari pada mahasiswa laki-laki $15,66 \%$. Hasil yang sama juga ditemukan pada penelitian Pinasti, (2020) yaitu participant perempuan memiliki persentase $69,2 \%$ dan paertisipant lakilaki berjumlah 30,8\%. Begitu juga dengan penelitian Fitri, et al (2020) bahwa sebanyak $75,7 \%$ responden pada penelitiannya berjenis kelamin perempuan dan $24,3 \%$ berjenis kelamin laki-laki.

\section{Mencuci Tangan Dengan Sabun}

Pada penelitian ini ditemukan sebanyak 93,97\% mahasiswa telah mencuci tangan dengan sabun dan air mengalir. Hal ini terlihat saat mahasiswa sebelum memasuki ruang kuliah, atau saat mahasiswa tiba di kampus. Hal yang sama juga ditemukan pada penelitian Fitri, et al (2020) dimana terdapat 94,8 \% mahasiswa telah mencuci tangan. Ketika sesorang mencuci tangan, maka siklus transmisi dan resiko penyebaran Covid19 antara $6 \%-44 \%$ dapat dikurangi (Cheng, et al., 2020).

Selain mencuci tangan dengan sabun, peneliti juga mendapati beberapa mahasiswa yang membawa dan membersihkan tangan menggunakan hand sanitizer. Hand sanitizer mengandung zat etanol, dimana etanol tersesbut memiliki aktivitas virucidal (Kampf, 2018). Sehingga, dengan penggunaan hand sanitizer, proses infeksi mikroba pada manusia dapat dicegah (Dewi et al., 2016). Menjaga kebersihan diri dengan mencuci tangan merupakan salah satu tindakan yang perlu dilakukan selama pandemi Covid19 ini (WHO, 2020).

\section{Etika Batuk}

Sebesar 98,79\% mahasiswa melakukan etika batuk dengan baik. Hal yang sama juga ditemukan pada penelitian Pinasti (2020). Penyebaran Covid-19 salah satunya melalui inhalasi kontak secara lansung dengan droplet pasien terinfeksi (Singhal, 2020). Saat ini, dalam beberapa kasus pasien terinfeksi Covid-19 tanpa menunjukkan gejala (Gao et al., 2020). Sehingga penerapan etika batuk bisa melindungi masyarakat dari pasien lain yang terinfeksi tanpa gejala. Etika batuk juga perlu dilakukan sebagai bentuk self protection agar terhindar dari infeksi Covid-19 (Nishiura et al., 2020).

\section{Pemakaian Masker}

Pada penelitian ini ditemukan $100 \%$ atau seluruh mahasiswa menggunakan masker saat perkuliahan maupun saat berada di lingkungan kampus. Hal ini sesuai dengan peraturan kampus bahwa mahasiswa yang tidak menggunakan masker tidak diizinkan untuk memasuki kawasan kampus. Hal yang sama juga ditemukan pada penelitian Fitri, et al (2020) bahwa sebagian besar mahasiswa yantu 97,8\% menggunakan masker. 
Masker merupakan pelindung wajah yang merupakan salah satu self protection selama pandemi Covid-19. Melalui penggunaan masker maka proses penyebaran Covid-19 dapat dikendalikan (Cheng, et al., 2020). Pengetahuan seseorang memiliki pergaruh terhadap kepatuhan pemakaian masker, dimana pengetahuan yang baik akan membentuk kepatuhan yang baik (Sari, 2020).

Pada penelitian ini peneliti juga menemukan terdapat beberapa mahasiswa yang menggunakan masker kain sebagai pengganti masker medis. Masker kain menjadi alternatif dalam upaya pencegahan COVID-19 (LPPM Universitas Diponegoro, 2020). Namun masker kain yang disarankan WHO adalah masker kain yang terdiri dari 3 lapisan kain (KEMENKES, 2020b). Namun, perlu diperhatikan bahwa penggunaan masker dalam waktu yang lama tidak dianjurkan karena dapat memunculkan penyakit lainnya (Szarpak et al.,2020).

\section{Physical Distancing}

Sebesar 96,38\% mahasiswa telah melakukan physical distancing dan masih terdapat mahasiswa yang tidak melakukan physical distancing. Hal ini juga sejalan penelitian Fitri, et al (2020) dimana terdapat $80,4 \%$ mahasiswa yang melakukan physical distancing. Tujuan dari physical distancing adalah untuk meminimalisir interaksi antar masyarakat yang kemungkinan telah terinfeksi namun tidak melakukan self isolation (Suppawittaya, et al., 2020). Physical distancing dapat dilakukan dengan menjaga jarak sejauh 1 meter atau 3 kaki dengan orang lain (WHO, 2020).

\section{KESIMPULAN}

Dalam penelitian ini dapat diambil kesimpulan bahwa mahasiswa telah menerapkan protokol kesehatan dengan baik, namun mahasiswa masih memiliki risiko terpapar Covid-19 yang tinggi.
Sehingga kedisiplinan dalam penerapan protokol kesehatan untuk mencegah penyebaran Covid-19 masih harus tetap diperhatikan.

\section{UCAPAN TERIMAKASIH}

Pada penelitian ini, peneliti mengucapkan terima kasih yang sebesarbesarnya kepada pihak Universitas Pahlawan Tuanku Tambusai, seluruh responden dan pihak yang terlibat dalam penelitian ini.

\section{DAFTAR PUSTAKA}

Cheng, V. C., Wong, S., Chuang, V. W., So, S. Y., Chen, J. H., Sridhar, S., To, K. K., Chan, J. F., Hung, I. F., Ho, P., \& Yuen, K. 2020. The Role of Community-Wide Wearing of Face Mask For Control of Coronavirus Disease 2019 (COVID-19 ) Epidemic Due to SARS-CoV 2. Journal of Infection, 81, 107-114. https://doi.org/10.1016/j.jinf.2020 .04 .024

Dewi, D. W., Khotimah, S., \& Liana, D. F. 2016. Pemanfaatan Infusa Lidah Buaya ( Aloe vera L ) Sebagai Antiseptik Pembersih Tangan Terhadap Jumlah Koloni Kuman. Jurnal Cerebellum, 2, 577-589.

Dinas Kesehatan Provinsi Riau. 2020. Informasi COVID-19. Diakses tanggal 24 maret- 05 april 2020.

Fitri, BM., Otik, W. dan Arfan, S. 2020. Penerapan Protokol Kesehatan Era New Normal dan Risiko COVID-19 pada Mahasiswa. Riset Informasi Kesehata. 9(2). ISSN 2548-6462

Gao, Z., Xu, Y., Sun, C., Wang, X., Guo, Y., Qiu, S., \& Ma, K. 2020. A systematic Review of Asymptomatic Infections with COVID-19. Journal of Microbiology, Immunology and 
Infection, $\quad \mathrm{xxxx}, \quad 1-5$. https://doi.org/10.1016/j.jmii.202 0.05 .001

Kampf, G. 2018. Efficacy of Ethanol Against Viruses in Hand Disinfection. Journal of Hospital Infection, 98(4), 331-338. https://doi.org/10.1016/j.jhin.201 7.08.025

Griffith K, Bureau KC. 2020. The 'new normal' after coronavirus [Internet]. 3KSN. [cited 2020 Dec 22].

Hermawan I. 2020. Kesiapan Pelaku Ekonomi Menghadapi Kenormalan Baru. Info Singk [Internet]. 12(11):19-24.

Kemenkes RI, 2020a. Gugus tugas percepatan penanganan COVID19. Diakses tanggal 17 maret- 05 april 2020.

Kemenkes RI. 2020b. Begini Aturan Pemakaian Masker Kain yang Benar. Www.Depkes.Go.Id [Internet].1-2.

Marpaung EWBH.2020. COVID-19 dan New Normal. Researchgate ;116.

Nishiura, H., Jung, S., Kinoshita, R., \& Yuan, B. 2020. Estimation of the asymptomatic ratio of novel coronavirus infections ( COVIDInternational Journal of Infectious Diseases. International Journal of Infectious Diseases, May, 19-21. https://doi.org/10.1016/j.ijid.2020 .03.020Pinasti, F.D.A., 2020. Analisis Dampak PAndemi Corona Virus Terhadap Tingkat Kesadaran Masyarakat dalam Penerapan Protokol Kesahatan.
Wellness and Helathy Magazine. 2(2). P 237-249.

Sari DP dan NS 'Atiqoh. 2020. Hubungan Antara Pengetahuan Masyarakat Dengan Kepatuhan Penggunaan Masker Sebagai Upaya Pencegahan Penyakit Covid-19 Di Ngronggah. J Ilm Rekam Medis dan Inform Kesehatan. 10(1):52-5.

Szarpak, L., Smereka, J., \& Filipiak, K. J. 2020. Cloth Masks Versus Medical Masks for COVID 19 Protection. Cardiology Journa, 27(April), 10-12. https://doi.org/10.5603/CJ.a2020. 0054

Singhal, T. 2020. A Review of Coronavirus Disease-2019 (COVID-19). The Indian Journal of Pediatrics, 87(April), 281-286.

Suppawittaya, P., Yiemphat, P., \& Yasri, P. 2020. Effects of Social Distancing, Self-Quarantine and Self-Isolation during the COVID19 Pandemic on People' s Well Being, and How to Cope with It. International Journal of Science and Healthcare Research, 5(June), 12-20.

Susilo A, Martin Rumende C, Pitoyo CW, Djoko Santoso W, Yulianti M, Sinto R, et al 2020. Coronavirus Disease 2019: Tinjauan Literatur Terkini [Internet]. Vol. 7, Jurnal Penyakit Dalam Indonesia.

WHO. 2020. Report situasional COVID19. Diakses tanggal 11 maret- 15 april 2020.

Worldometer. 2020. Corona virus pandemic. Diakses tanggal 12 maret- 17 april 2020. 